modernize his farm and to increase its productivity, will meet with continuous support from the State."

Last Saturday, at the meeting of the Party Central Committee, First Secretary Stanislaw Kania was even more forthcoming. "Individual peasants carry the Society", he said. "We shall ensure that every peasant is certain of his ownership and his farming tenure."

The next few months should show how far practical policy implements these assurances.

Vera Rich

\section{Kopek interferon}

Last week, the Soviet news agency TASS announced that interferon can be purchased in any Soviet drug store for 56 kopeks per ampoule. The Soviet Union, said TASS, was the first country to produce interferon commercially, and for more than a decade Soviet doctors have been using interferon to prevent influenza and other virus diseases of the respiratory tract. Soviet doctors, said TASS, also use interferon against leukaemia and viral skin diseases. A patent for interferon production has been purchased from the Soviet Union by Japan.

What the TASS announcement does not make clear, however, is the extremely low dosage in the 56 kopek ampoule. Samples analysed in Western laboratories contained dosages of the order of 1,000 units or less. The market price of Finnish interferon is US $\$ 25.00$ per million units. At 64.4 kopeks to the dollar, Soviet interferon is therefore by no means competitive.

A careful reading of the TASS interview with Dr Valentin D. Solov'ev, moreover, reveals that studies on leukaemia, skin diseases, and also the veterinary use of bovine and porcine interferon, are still at the experimental stage. It is only the interferon nose-drops, which Dr Solov'ev himself pioneered in 1968, that are in regular use. However, Western experts find it difficult to understand the discrepancy between their results and those of $\mathrm{Dr}$ Solov'ev. In the West, interferon has been used successfully to prevent respiratory virus infections, but only at high doses and in patients with little or no natural resistance.

As far as mass prophylaxis is concerned, as the British Medical Journal observed recently, since interferon, like any intranasal liquid, has only a short half-life in the nasal cavity, but needs long-term contact with the nasal epithelial cells in order to make them more resistant to virus infection, "it is therefore difficult to understand how . . . nose drops containing a low titre of human leukocyte interferon could cause the degree of protection under epidemic conditions reported by Dr Solov'ev".

Vera Rich

\section{Gulf pollution}

\section{UN's other worry}

War is the greatest immediate threat to the Middle East - but the destruction of its fragile water supply, the Gulf itself, must be next. At the end of this month local marine scientists meet in Kuwait, next door to the Iraq/Iran conflict, to pledge research spending of up to $\$ 5$ million over two years to find out exactly what is happening to the waters of the Gulf.

The long-term development of the region, the Gulf States have recently recognized, depends on proper environmental management of the Gulf and its coastal regions; yet little is known of its ecology, oceanography or meteorology. The water of the Gulf is needed for agriculture, coastal industries, and for drinking, yet the highest density of tankers in any ocean discharges its ballast into it, and many industries such as desalination plants with their associated chloralkali works (using mercury catalysts), aluminium smelters (emitting (emitting ammonia), and refineries (sulphur dioxide and hydrocarbons) belch out completely uncontrolled emissions. Already seafood is frequently tainted with oil, and city environments have hydrogen fluoride), fertilizer plants

Gulf States. Sewerage networks and treatment plants will serve the whole of Kuwait by 1982 , Qatar by 1985 . But Bahrain's system is not planned to be complete until 2008, and Saudi Arabia's treatment plant on the Gulf is overloaded.

Hence the effort, catalysed by the Regional Seas Programme of the United Nations Environment Programme (UNEP) to undertake research into the sources and impact of pollutants. At present there are relatively few institutes in the region capable of doing the research, but the picture - UNEP estimates - will be "drastically changed" within a year. UNEP, with its experience in the Mediterranean pollution programme, will help with training, but the Gulf States will jealously guard their technical independence: they have no wish for "expert" teams descending from outside.

At Kuwait, seven research projects will be discussed. The most likely to be funded concerns oil: what are the principal sources of oil pollution in the Gulf, how is the oil distributed, and what are its effects on human health and the marine and coastal ecosystems? But to understand this question, the basic physical and chemical oceanography of the Gulf must be studied, and the biological balance of the sea understood.

Meteorology is also important. The

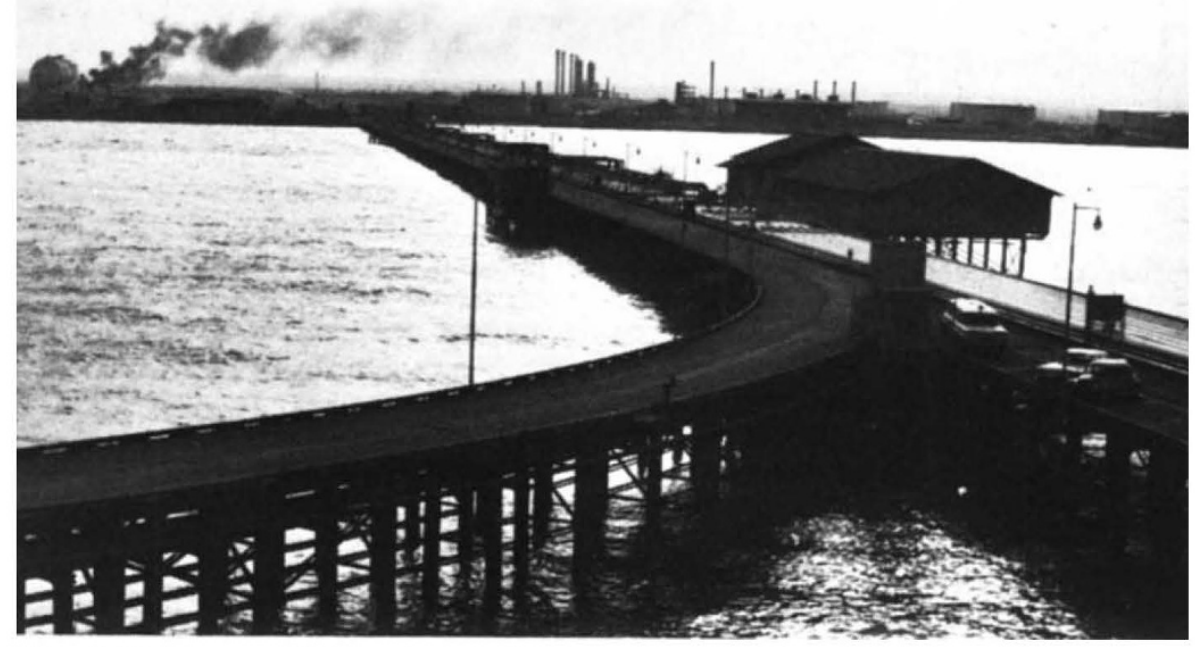

Kuwait Harbour, twentieth century skyline

deteriorated markedly in the past two or three years.

There are also at least 20 major industrial development regions around the Gulf coast, enjoying the world's greatest rate of development, and populations are flooding to these areas from the interior. Often the legal or institutional mechanisms do not exist to control pollution. And all this is threatening a sea on average only 35 metres deep, which evaporates more water than it receives from river run-off. (The Indian Ocean contributes the balance, through the Straits of Hormuz.)

Sewage is coming under control more rapidly than other pollutants, because of the existence of international contracting companies which are selling systems to
"Shamal", winds blow dust which sediments much of the surface oil; Kuwait suffers frequent calms and temperature inversions which trap airborne emmission. Coastal mining is affecting wave erosion and sedimentation patterns, which could in turn affect access by the supertankers; Gulf currents at all depths must be measured. What is the residence time of water in the various regions of the Gulf? This question affects the concentrations that pollutants might be expected to reach.

Other studies would measure the levels of heavy metals in economically important marine organisms; and investigate the distribution and sensitivities of plankton, the lowest level of the food chain.

Robert Walgate 